\title{
The mining policy of the Philippines and «resource nationalism» towards nation-building
}

\section{Minerva Chaloping-March}

\section{OpenEdition}

1 Journals

\section{Electronic version}

URL: http://journals.openedition.org/jso/7067

DOI: $10.4000 /$ jso. 7067

ISSN: $1760-7256$

\section{Publisher}

Société des océanistes

\section{Printed version}

Date of publication: 15 December 2014

Number of pages: 93-106

ISBN: 978-2-85430-118-2

ISSN: 0300-953x

\section{Electronic reference}

Minerva Chaloping-March, «The mining policy of the Philippines and «resource nationalism» towards nation-building », Journal de la Société des Océanistes [Online], 138-139| 2014, Online since 15

December 2017, connection on 10 December 2020. URL : http://journals.openedition.org/jso/7067 ; DOI : https://doi.org/10.4000/jso.7067

\section{(c) (†) $\odot$}

Journal de la société des océanistes est mis à disposition selon les termes de la Licence Creative Commons Attribution - Pas d'Utilisation Commerciale - Pas de Modification 4.0 International. 


\section{The mining policy of the Philippines and «resource nationalism» towards nation-building}

by

\section{Minerva CHALOPING-MARCH ${ }^{*}$}

\begin{abstract}
This paper looks at the extent to which the Mining Act of 1995 responds to the aspirations of citizen constituencies such as local governments. The law provides the regulatory and institutional framework for the operation of large-scale mining in the hope that substantial foreign capital is brought into government coffers. The law also provides for mechanisms to ensure community consultation, local government empowerment, concern for the indigenous communities, and equitable benefits sharing. However, the national government - with the country's minerals industry - has focused on foreign investments at the expense of equity and benefit allocations for local communities. Several local governments have blocked the entry of large-scale mining or forbidden open pit mining. Such action, including new local legislations, manifests sub-national resource nationalism that is founded on locality and affinity to homeland, and confronts the national government in matters of resource governance.
\end{abstract}

KeYwords: resource nationalism, Philippines Mining Act, local governments, social imaginaries, mining policy

In current literature, most discussions on resource nationalism have focused on its causes and manifestations (Clarke and Cummins, 2012) particularly its impact on industry and investment patterns on the producing country and the risks on the part of investors (Bremmer and Johnston, 2009; Emel, Huber and Makene, 2011; Ernst and Young, 2013). Resource na-

\section{RÉSUMÉ}

Cet article examine l'adéquation de la loi minière de 1995 aux aspirations de la représentation citoyenne, dont les gouvernements locaux. Cette loi fournit le cadre régulateur et institutionnel pour l'accueil de grands projets pour financer le budget de l'État. Elle offre aussi des mécanismes garantissant la consultation des communautés, le renforcement des pouvoirs des gouvernements locaux, le respect des communautés autochtones et un partage équitable des bénéfices. Mais le gouvernement national - avec l'industrie minière du pays - s'est concentré sur les investissements étrangers aux dépens d'une redistribution équitable. Des gouvernements locaux ont interdit le démarrage de gros projets miniers ou l'extraction à ciel ouvert. Ces actions, incluant la promulgation de lois locales, expriment un nationalisme des ressources "infranational" ancré dans la localité et le lien au territoire et opposé au gouvernement national en matière de gouvernance des ressources

Mots-clés : nationalisme des ressources, Philippines, Loi minière, gouvernement local, imaginaires sociaux, politique minière

tionalism is viewed as a cyclical phenomenon (Stevens, 2008) and is one in which the global and the national landscapes and their relationship with one another are "tested and refined» (Ward, 2009). In certain cases, these global-national landscapes are characterized by long-term extractive industry dependency that restricts policy options of the producing country (Kohl and

* Development Anthropologist, Senior Research Fellow, Philippines-Australia Studies Centre, La Trobe University, m.chaloping-march@latrobe.edu.au 
Farthing, 2012). Resource nationalism has been investigated as a demonstration of a resourceendowed country's motivation to expand its share of resource rent.

What has remained largely unexamined includes the complex interactions in resource nationalism and the main actors involved other than the host country and the foreign investors. There is scarce understanding about whether a resource nationalist position of a state is shared or concurred, or conversely, challenged by its citizens. This paper deals with these issues by examining the case of the Philippines. The paper looks into constituent citizens confronting the centralized control of the State over mineral resources and their development and exploitation. The paper begins with some definitions of key terms such as "resource nationalism» and «sovereignty» pertinent to mining. I then proceed to look into the economic liberalization policy embraced by the Philippine state. This brings the discussion to the enactment of a new mining policy in 1995. The passage of this law and the process of implementing it have provided a context for the collision of several perspectives on «development» and ideas of equity, locality, and sovereignty. I present the narratives which form part of social imaginaries of the key actors in mining. The paper ends by tying together the key points I earlier raised towards the conclusion: resource nationalism is not plainly an assertive posturing of a government pertinent to administering resource extraction. Rather, resource nationalism is rooted in connectedness to a homeland. Given their shared experiences and common visions of change in the status quo, key sectors of the Philippine citizenry forge actions to confront the Philippine state.

For this paper, I use some of the fieldwork data collected during my $\mathrm{PhD}$ research (June - Aug 2003, July 2004 to May 2005), and interviews during separate fieldworks in March-April 2010 and August 2011. I add some data generated through interviews which I carried out for a recent project ${ }^{1}$ in December 2013-January 2014. These are supplemented by information synthesized from archival materials and critical review of published literature, government documents, and press releases.

\section{Mining and resource nationalism}

The continuity of mining as a global industry depends on the availability of minerals to ensure a stable supply of commodities. However, a reality in mining as an economic activity is the immobility of mineral resources. Considering that minerals are in situ, mining companies have to go to the areas where the resources are found. A host country accommodates foreign companies to carry out mining within its territory. An investing company receives rights to extract minerals under conditions which are largely defined by the political, institutional, socio-economic and cultural landscape of the host country. Thus a mutually interdependent relationship develops: the host country relies on the mining company for foreign capital while the latter is granted certain rights in extracting minerals.

Over time, the form and scope of this contractual relationship undergo changes. The ensuing changes have important implications for pursuing the interests of each party. It is during this instance when resource nationalism not only manifests itself but is re-examined by the host government. Resource nationalism involves actions and motivations of a resource-endowed country to ensure primacy over the development of its mineral resources vis-à-vis the participation of foreign investors. It represents the attempts of the host country's assertion of greater control over how the mineral resources located within state territory are developed in order to maximize government revenues from production.

During the 1980s through 1990s, resource-endowed countries centred on attracting foreign investment by boosting the competitiveness of their fiscal regimes for mining. This meant that their policies established generous terms in favour of mining companies. Heeding to recommendations of international financial institutions such as the World Bank (Haselip and Hilson, 2005; WB-IFC, 2003), many developing countries revised their mining policies. This was a trend that reflected in part the stiff competition and the apparent exigency to stir and promote mining investments (Smith and Naito, 1998). During the period 1985 to 1995 , there were over 90 countries that legislated new mining laws, revised substantially their prevailing mining policies, or were formulating new legislation (Otto, 1997). Policy changes made by developing countries include simplifying permitting procedures to provide flexibility in investment agreements. In addition, taxation schemes were becoming more comprehensive to both attract investors and maximize government revenues (UNCTAD Secretariat, 1997).

However, the situation has changed in the several years that followed. By 2003, commodity prices have soared. Host countries have become more concerned about obtaining a bigger cut of the mining revenue pie (Gravelle, 2012). The rise in commodity prices prompted producing countries to raise royalty and taxation in their 
attempt to maximise their income revenues. The overall global trend is an increase in the tax burden on mining companies as host governments regard mining companies to be making ample profits in light of soaring mineral prices.

In the Philippines, the current president Benigno Simeon Aquino III issued on July 2012 Executive Order 79 (2012), which makes modifications of the Mining Act of 1995 and articulates the mining policy of his administration. The issuance of Executive Order 79 is partly due to the growing clamour of various stakeholders (i.e., local governments, communities and civil society groups) for a fair share of the value of extracted resources. In addition, these stakeholders claim that there has been lack of meaningful involvement of communities in decisions and initiatives affecting them. Resource nationalism, as this paper discusses, involves what community citizens regard as the core of managing resources for the good of communities. This refers to affinity to the place where a resource is found - and such sense of attachment exists only among local residents. Hence, the idea of "development" that appeals to local communities is that which involves their initiatives, systems, and knowledge in the utilization of natural resources and subsequently benefit them.

\section{Sovereignty and Mineral Resources}

A key notion that is closely tied to resource nationalism is "sovereignty». The modern concept of this term is traced to the French jurist and political philosopher Jean Bodin who made the earliest discussion of the theory of sovereignty. According to Bodin (1955: 24), sovereignty is that «absolute and perpetual power vested in a commonwealth». For the purpose of this paper, we take the quintessence of the term that is expressed in Bodin's definition - the power of a state. Bodin noted that this power:

«is in the first place absolute, in that it is wholly free from the restraint of law, and is held subject to no conditions or limitations» (Merriam, 2001: 7) ${ }^{2}$

In our present-day world, sovereignty of the state is associated mainly with the idea that states have the power to run their own affairs, including how mineral resources must be extracted, by whom and under what terms.

A sovereign state is an autonomous entity and no state has a right to intervene in the internal affairs of another. Sovereignty is a principle as well as a practice (Litfin, 1997). It is not an «either or" matter. A state must not be regarded as either "having» or "not having» sovereignty. Rather, as Yasin (2010) clarifies, sovereignty is a matter of degree. James Rosenau (1995: 195) explains that the sovereignty of a state must be understood as lying within a continuum ranging from "convenience-of-state» at one end, to «states-are obliged-to-go along» at the opposite end. This means that depending on situations, the state relocates its sovereignty from one point to another along the continuum.

In a global economic system, a resource-endowed country becomes open to external economic events beyond its control. It finds itself inviting foreign investors in order to generate adequate capital to be able to fully participate in the global market. The strength of the state is tested and demonstrated in the ways by which it accommodates the demands of the global economy. It might appear that as the state fulfils the requirements of regional or transnational bodies, its power as a sovereign entity is allocated away. However, this is not so. The allocation of power "away» from the state is authorized or consented and that the consenting entity remains and is always the state (Yasin, 2010). Rosenau further clarifies that under conditions of globalization, sovereignty is both saturated by and placed within dynamic, persistently repetitive, turbulent political processes.

The two elements that are vital to the idea of sovereignty are control and authority (Nagan and Haddad, 2012: 435). Litfin (1997: 169) adds a third one which is essentially the most critical as far as the Philippines is concerned, i.e., legitimacy, which he defines as the «recognized right to make rules». The concept of legitimacy incorporates a clearly normative component and is reinforced by control and autonomy. This means that the idea of sovereignty does not apply only to a state's relationship with external bodies. Rather, a state's sovereignty in governing resources involves establishing and maintaining legitimacy before its citizens.

In the specific case of the Philippines, the 1987 Constitution (Article II Section 2) declares the following:

"The Philippines is a democratic and republican State. Sovereignty resides in the people and all government authority emanates from them.»

2. Bodin was not advocating for an absolutist state. It would be clearer to view Bodin's idea of sovereignty in the context of the political chaos of his time. According to Nagan and Haddad (2012) the public order of Europe and the idea of Christian universality were crumbling under the influence of the Reformation. The end of the Holy Roman Empire marked the weakening of Christian Universalism in Europe and in turn a legacy of religious wars. These wars seemed unending and generated social disorder and anarchy. 
The Philippine national government, in cooperation with the country's mining industry - mainly through the Chamber of Mines of the Philippines (COMP) - has been feverishly promoting mining as the engine of economic growth. However such action has caused factions among other key stakeholders in mining. As an economic activity and as an industry, mining has prompted debates involving views from government agencies, mining executives, academicians, economists, local government officials as well as representatives of the religious sector, indigenous organizations, and environment and conservation groups. There are several reasons why mining remains a polemical subject matter in the Philippines:

a) an earnest goal, or desperate objective, within the national government to address fiscal difficulties,

b) an eager anticipation of business and industry groups to seize opportunities for foreign investment in mining,

c) a genuine concern of many citizens about the long-term adverse social and environmental consequences associated with mining activities, including the cultural and economic wellbeing of communities especially after a mine operation has long shut down,

d) a lingering distrust of many citizens in the ability and sincerity of the national government and the minerals industry to address the concerns of communities who are adversely affected by mining operations, and

e) a continuing doubt and skepticism among organized citizen groups that exploitation of minerals by foreign companies is the right path to national development.

In other words, the actions of the Philippine national government, which include granting foreign investors nearly monopolistic rights over mineral resources and entitling them enormous tax incentives, is not fully supported by several sectors of the Philippine citizenry. The national government's granting priority rights to those who have the foreign capital, and undermining the aspirations of local citizens, negates nationalism. The overcentrality of control by the national government in directing the exploitation, development and utilization of mineral resources repudiates local initiatives and mechanisms in addressing resource and environment concerns. In effect, enormous setbacks have dragged the full implementation of the Mining Act. Until the present, the law has continued to saunter a thorny path.

\section{Economic Liberalization: Launching Phase and Full Realization}

In the early $1990 \mathrm{~s}$, the $12^{\text {th }}$ President of the Philippines, Fidel V. Ramos, pursued his administration's grand industrialization scheme that aimed to rejuvenate the country's economy. Known as the "Philippines 2000», Ramos envisioned the Philippines to join the newly industrializing countries by the year 2000 . The program components are outlined in the Philippine Medium-Term Development Plan for the years 1993-1998. It emphasized the need to achieve global competitiveness for the Philippines (Ramos, 1993). The Plan called for a continuation of the policy of liberalization, deregulation, and globalization (Jurado, 2003) that was started by Corazon Aquino, Ramos's predecessor.

During her term, Aquino began liberalizing the economy that involved privatization of more than 250 government-owned and controlled corporations (Gonzalez III, 2001). Aquino issued Executive Order 279 in July 1987 to foster investment in the mining industry. This law gave authority to a cabinet-level officer, the Secretary of the Department of Environment and Natural Resources (DENR), to "enter into, for and in behalf of the Government», business transactions such as joint venture or production-sharing agreements that involve the exploration, development, and utilization of mineral resources "with any Filipino citizen, or corporation or association at least sixty percentum of whose capital is owned by Filipino citizens» (Executive Order 279, 1987, Section 1). This authority which was formerly a prerogative reserved only for the President of the Philippines was intended to ease, as it did, the entry of many foreign mining companies.

Succeeding Aquino as President, Ramos opened more extensively the doors to foreign investors for all industries: deregulating, liberalizing and privatizing almost all government owned corporations. The Philippines was one of many developing countries to adopt neo-liberal economic policies to attract more mining investments.

\section{The Mining Act of 1995}

Under President Ramos, Republic Act 7942, known as the Philippine Mining Act of 1995, was approved. As hoped for by the national government, the passage of this law led to the entry of foreign investors. Scarcely a few months after the law was passed, more than 50 applications for financial technical assistance agreements (FTAAs) were already filed at the Mines and Geosciences Bureau (мGB). In 1996, 20 of the world's largest mining companies established offices in the Philippines. They filed applications for various mining tenements. Subsequently, the applications led to the approval of several exploration projects (Cabalda, Banaag, Tidalgo, and Garces, 2002) and brought euphoria within the Chamber of Mines of the Philippines (сOMP), the MGB and the national government. 
Under the Mining Act, there are three types of permits: an exploration permit, a mineral agreement, and a financial technical assistance agreement (FTAA). A detailed discussion of each is not permissible in this paper due to limited space. Among the three, the FTAA has been the most controversial. It is an agreement between a contractor and the Government of the Philippines and allows 100\% foreign ownership. It grants the contractor rights for large-scale exploration, as well as development and utilization of minerals. An FTAA has a term of 25 years, and extendable for another 25 years. It requires a minimum committed investment of US\$ 50 million for infrastructure and mine development. The terms and conditions of the contract, including the government share, are negotiated. The Mining Act also grants mining companies to occupy an area of 81,000 hectares where the company enjoys timber rights, water rights and easement rights. The incentives granted to foreign mining companies include tax holidays and 100\% repatriation of their capital and profit.

The avenue given to foreigners to fully own and control mining operations in the Philippines has become an extremely contentious issue. The situation has triggered what Rosenau describes as 'turbulent processes' that have defined the ebb and flow of the Mining Act's implementation.

\section{Social Imaginaries}

In this paper, I use the term social imaginary as elucidated by the philosopher Charles Taylor. He observes that community populations come together to envision their lives in particular and often instinctively shared ways. Taylor refers to these as «social imaginaries». Taylor explains:

"Our social imaginary at any given time is complex. It incorporates a sense of the normal expectations we have of each other, the kind of common understanding that enables us to carry out the collective practices that make up our social life. This incorporates some sense of how we all fit together in carrying out the common practice. Such understanding is both factual and normative; that is, we have a sense of how things usually go, but this is interwoven with an idea of how they ought to go, of what missteps would invalidate the practice.» (2004: 24)

Taylor asserts that a social imaginary involves «something much broader and deeper than the intellectual schemes people may entertain when they think about social reality in a disengaged mode». Taylor describes:
«I am thinking, rather, of the ways in which people imagine their social existence, how they fit together with others, how things go on between them and their fellows, the expectations that are normally met, and the deeper normative notions and images that underlie these expectations.» (2004: 23)

In other words, a social imaginary incorporates normative ideas, i.e., how matters ought to be based on how processes or systems have been carrying on. Thus, a social imaginary blends both factual and normative dimensions of social existence. It plays an important role in understanding, orchestrating, and promoting development in a society. Key sectors of the Filipino population generally share narratives pertinent to what they consider as «development». Actions pertinent to realize desired changes in the status quo, and other initiatives which are directed at achieving betterment of economic, environmental and social conditions all embody a social imaginary, and are expressed in narratives of key players in mining, about which I now turn to.

\section{National Government}

The 1987 Philippine Constitution (1987, Article 12 Section 2) declares that the Philippine State owns

«all lands of the public domain, waters, minerals, coal, petroleum, and other mineral oils, all forces of potential energy, fisheries, forests or timber, wildlife, flora and fauna, and other natural resources.»

\section{In addition,}

"the exploration, development, and utilization of natural resources shall be under the full control and supervision of the State.»

This is a critical premise and a clear fact that is wellaccepted by all sections of the Filipino population.

The narrative of key government officials pertinent to economic development is encapsulated in key phrases enunciated by former President Ramos in his state of the nation address in 1993. He presented his program that was hailed as the «Philippines 2000». Ramos stressed that the Philippines has to engage in "opening the economy» in order to be at par with competing countries, "dismantle the structure of protectionism and controls», and alleviate poverty which is the "central thrust of all our programs» (1993, emphasis supplied). These ideas have been re-echoed in the Mining Act of 1995 and reiterated in a law issued by Ramos's successor Gloria MacapagalArroyo. Executive Order $270^{3}$ (2004, emphasis supplied) states: 
«It shall be the policy of the Government to promote responsible mineral resources operation, development and utilization, in order to enhance economic growth, in a manner that adheres to the principles of sustainable development and with due regard for justice and equity, sensitivity to the culture of the Filipino people and respect for the Philippine sovereignty."

Executive Order 270 is impressively benevolent and democratic in its rationale and intent, and is also extensive in its coverage. Furthermore, it declares as its guiding policy the following (2004, emphasis supplied):

"Government recognizes the critical role of investments in the minerals industry for national development and poverty alleviation and shall provide support mechanisms for a sustained mineral exploration program, responsive research and development priorities and capability building for industry manpower; Clear, stable and predictable investment and regulatory policies shall be instituted to facilitate investments in mining, leading to a prosperous minerals industry; Value-adding as a measure of optimizing benefits from minerals for the Filipino people shall be pursued through the development of downstream industries to achieve greater productivity and efficiency.»

Represented mainly by the Office of the President, the MGB, the Department of Trade and Industry, the National Economic Development Authority and other agencies, the national government regards mining as a critical means to pave the country's path to industrialization by generating wealth, employment and other benefits in both rural and urban regions (Defensor, 2005). The national government acknowledges its need for strong partnership with the minerals industry. Thus, true enough, both key government agencies and the COMP have bonded themselves into a solid and busy team in marketing to foreign investors the Philippines as an investment destination.

In early 2005, representatives of the national government and top officers of the сомp had engaged in what they termed as 'mining roadshows' in various parts of the world including China, Singapore, South Africa, Canada and Australia ${ }^{4}$. These roadshows consisted of meetings and discussions with foreign investors on mining investment opportunities in the Philippines. Subsequently in 2006, the COMP organized an international investment mining conference in the Philippines attended by re- presentatives of foreign mining companies. The purpose was to promote the mineral prospects of the Philippines particularly the 24 priority mining projects 5 . As earnestly hoped for by COMP, the conference resulted in the signing of many Memoranda of Understandings (MoUs) and letters of intent between foreign mining companies and local mining partners (Disini, 2006).

\section{Local Governments}

The welcoming stance of the national government towards mining projects and the enthusiasm of the COMP in promoting the Philippines as a haven for mining investments have not been shared fully by a few local governments. Across the Philippines there have been varying degrees of local government inhospitality towards potential mining projects within their specific political-geographic jurisdictions. Republic Act 7160, otherwise known as the Local Government Code of the Philippines (1991) devolved certain functions - such as environmental management - to local government units which include provincial, municipal and barangay ${ }^{6}$ («village») levels of governance.

One of the local governments that has demonstrated early unreceptiveness towards mining is the provincial government of Capiz that imposed in 1999 a 15-year moratorium on all largescale mining (Capiz Provincial Ordinance No. 6, 1999). Similarly, the Oriental Mindoro provincial government declared in 2002 a 25 -year freeze on 'large-scale mining or extraction in all forms' (Oriental Mindoro Provincial Ordinance No. 01-2002, 2002). The following provinces also have legislations disallowing large-scale mining operations within their jurisdictions:

- Albay (ordinance took effect in March 2011),

- Bukidnon (ordinance took effect in May 2011, buttressing a related legislation passed in 2009),

- Occidental Mindoro (ordinance took effect in 2009),

- and Zamboanga del Norte banning specifically open pit mining (ordinance took effect on November 2011).

The most controversial opposition to mining by local governments, supported by their constituent citizens, have been waged in Palawan (MISN, 2010), Romblon, and South Cotabato (Minda News, 2011a, 2011b) because the local

4. The «mining roadshows» in Australia were held in three cities namely Melbourne, Sydney and Brisbane. The author attended the one held in Melbourne on 10 August 2005.

5. The 24 priority mining projects include potential medium- to large-scale mining ventures many of which need capital which local mining companies lack.

6. The barangay is the smallest and most basic administrative political unit in the Philippines. A group of barangay makes up a municipality. A cluster of municipalities constitutes a province. In 2011, there are 42,027 barangays in the entire Philippines (DILG, 2011). 
laws are being challenged by mining companies and the MGB-DENR, both arguing that national government laws have primacy over local government laws. However, in August 2013, the DENR Secretary conceded not to challenge South Cotabato's ban on open-pit mining (Business Mirror, 2013b). Meanwhile, the governor of Romblon has reaffirmed his resolve to challenge the resolution issued by a Regional Trial Court that rendered Romblon's provincial ordinance, placing a moratorium on mining, as unconstitutional (Business Mirror, 2013a). While disputations have been continuing until the present, the initiatives of some provinces in legislating ordinances to restrict mining operations, are likely to trigger other provinces to follow suit.

Under the Mining Act and its implementing rules and regulations, local governments are envisaged to realize wealth creation from mineral resources to drive growth and provide livelihood and income opportunities for their constituencies. In particular, the Mining Act provides that local governments are entitled to a $40 \%$ share from the gross collection of the national government from mining taxes, royalties and other fees. In addition, occupation fees entitle the province to $30 \%$, and host municipalities to $70 \%$. These provisions are strengthened by the Local Government Code. Section 292 stipulates that if a natural resource is located in the province, then the provincial government will have a share of $20 \%$; municipality, $45 \%$; and the barangay, $35 \%$ out of the $40 \%$ revenue that the national government remits to the local government.

These all seem auspicious. However, local governments receive their share of tax revenues at a much delayed time. The yearly taxes collected from mining operations accrue to the national treasury and it would take at least a couple of years for a local government to collect its fund allocation. The insight of a mayor of a mining municipality offers a picture of the situation.

"Our hometown as you know very well is a place of mining. But take a look around and tell me, have we progressed significantly through the 80 -decade-long operation of that company? The company has been paying its taxes to the national government every year. We had to wait like beggars for decades before we receive our internal revenue allotment from the national government. As for our latest allotment, it is debasing that we have been prodding the national government since 2000 to remit about PhP87 mil- lion to us as part of our share in the excise taxes paid by mining companies. We are not supposed to beg the national government but we are compelled to, lest we will never get the money that belongs to us.» (Interview on November 2004, Poblacion, Itogon, Benguet)

The misgivings of local government officials towards the national government about revenues from mining are also expressed in the views of a prominent member of the League of Provinces of the Philippines (LPP) ${ }^{7}$. During the 9th General Assembly of the LPP in 2012, Governor Joey Sarte Salceda described the MGB as needing to heed to the "doctrine of local preference and the philosophy of subsidiarity» in administering mining projects (Bicol Mail, 2012). This implies that provincial, municipal, and barangay levels of government must be the bodies to grant approvals for mining projects. Salceda also noted that at the same time, mining companies must pay taxes direct to the provincial and municipal governments. Salceda is the governor of Albay, the location of Rapu-rapu mine which became the first large-scale mining project that opened in the Philippines - and eventually advanced to production stage - after almost three decades during which no new mine in the country commenced operation.

The criticism against revenues from mining is not only about long delays experienced by local governments in receiving their allocated share. More important is the ratio of local government allocation relative to how much is ultimately taken by the mining companies. Salceda is a major critic of what he considers an austerely «Liliputian» share of local governments from mining. In 2010, mining companies in the Bicol Region ${ }^{8}$

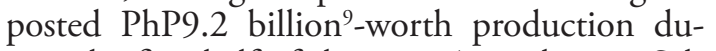
ring the first half of the year. According to Salceda, the mammoth amount was for the mining companies, not for the people in the region. He added that mining companies paid PhP647 mil$\operatorname{lion}^{10}$ in taxes to the national treasury and remitted a meager share of only PhP90 million ${ }^{11}$ to local governments (Southern Luzon Business Review, 2011).

The concerns of local governments are not limited to the perceived miserly revenues from mining. The reasons for local governments' hindering the entry of mining projects, or restricting certain methods (e.g., open pit) of mining

7. The League of Provinces is a formal organization whose creation is mandated by the Local Government Code. Its objectives, among others, include: to foster unity and cooperation among all provinces of the country, and to serve as a forum of discussion and feedback mechanism on policies affecting local governments.

8. Albay and five other provinces (Camarines Norte, Camarines Sur, Catanduanes, Masbate and Sorsogon) comprise the Bicol Region. Each of the provinces has mining operations.

9. PhP9.2 billion equates to roughly US\$206 million $(\mathrm{PhP} 0.0224=\mathrm{US} \$ 1)$.

10. PhP647 million is about US $\$ 14.5$ million.

11. PhP90 million is approximately over US $\$ 2$ million. 
within their jurisdiction, include the perceived need to protect, conserve and rehabilitate the environment; judiciously and equitably use natural resources; and consult with community members (Business Mirror, 2013a; Cleanbiz Asia, 2013; Philstar, 2013; South Cotabato Provincial Ordinance No. 04, 2010). The foreseen repercussions of mining operations on the environment, are expressed in the explanation of a $b a$ rangay chairman why he and his community are opposed to mining:

"We do not want mining here in our barangay. Our water sources are being destroyed. We are alarmed. Any mining operation is a major disruption in nature's processes. This means mining brings a serious threat to our water sources, and an invitation to landslides and flashfloods. It is us, the people in the barangay, that will suffer the harmful consequences of mining. It is not those at the MGB and the executives of mining companies much less the foreigners that own the companies. They do not feel what we feel because they are not of this place. They do not understand our situation, and they cannot sympathize with us. They come here and stay only as visitors. The MGB and mining companies insist that digging our minerals is what needs to be done. That is their own idea, not ours. They do not live our lives that is why they see our coconut farms as dispensable. But this is our place; we have no other.» (Interview on 30 December 2013, Labo, Camarines Norte)

The above insight underscores the attribute of rootedness in a place - the locale. It suggests ideas of concord and affinity with the locality. According to local government officials, an understanding of local situations is a trait which is manifestly lacking among representatives of the national government and the minerals industry. The above remark also draws attention to the notions of domain and locality, which are absent in the discourse of national government officials. The claim to locality and attachment to place reechoes the viewpoint of Arthur Pingoy, the governor of South Cotabato Province whose environment code bans open pit mining. In a press release where he was asked about his reaction to Executive Order 79, the governor stated :

«Our ordinance stays unless its validity is challenged in court... We in the local government are in the best position to know what is good for our people and the environment. I will continue to implement the law (anti-open pit ordinance) unless it is declared by the court illegal.» (2004: 24)

The concerns of local governments essentially incorporate the views and aspirations of local communities that include specific sectors such as farmers, fishermen, and in several cases, indigenous peoples. In general, local ordinances become the formal shields of communities against the probable entry of mining projects into their towns or villages. In the same manner, local officials make public declarations that the legislations they enacted are based on consultations with their constituencies. Thus far, this is the case, broadly, of South Cotabato and Romblon. Unfortunately in other places (e.g., Cantilan in Surigao del Sur, Didipio in Nueva Vizcaya), communities are divided in which members are lamentably categorized as either "pro-mining» or «anti-mining».

\section{Civil Society}

When it comes to dealing with the actions of the combined strength of the state and the minerals industry, some local governments and communities who are not convinced about the wisdom of opening their doors to mining, look for support. At both the national and village levels, some help is often found in the Roman Catholic Church. Catholic clergymen, particularly members of the politically influential Catholic Bishops Conference of the Philippines (СвСР), raise an ethical issue pertinent to mining: the land must not be «defiled», the environment protected and the disadvantaged sectors particularly the indigenous peoples must not be displaced.

The clergymen are supported by the advocacy activities carried out by nationalist groups that tend to be ideological in orientation and whose rhetoric appeals to citizens and communities desperate for support. Their discourse includes claims to stop the entry of transnational mining companies into the Philippines, and views that foreign mining companies are «imperialist plunderers». Many nationalist organizations are either directly allied with or sympathetic to bayan

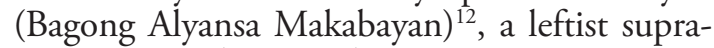
organization that coordinates mass movements. bayan takes a political position during elections and represents peasants, industrial workers, women, public transport drivers, teachers, indigenous peoples, and others. bayan organizations are overtly revolutionary and seek involvement in any constituency of resistance that they can identify.

In many ways, non-government organizations (NGOs) and peoples' organizations (POs) derive their reason for being, as well as the legitimacy and stability of their avowed causes from communities. One of these NGOs is the Alyansa Tigil Mina $^{13}$ (ATM) which plays a significant role in

12. Bagong Alyansa Makabayan means «The New Patriotic Alliance». For related information, see http://www.philippinerevolution.net.

13. Alyansa Tigil Mina stands for «Alliance Against Mining». More information is available at http://alyansatigilmina.net/. 
providing the channel through which communities have been able to articulate their apprehensions towards mining projects. ATM is an alliance of large and small organizations with the common cause of confronting «the official line of thinking about mining». The ATM (2014) is:

«[...] a coalition of organizations and groups who have decided to collectively challenge the aggressive promotion of large-scale mining in the Philippines. Composed of Non-Government Organizations, People's Organizations, Church groups and academic institutions, the ATM is both an advocacy group and a people's movement, working in solidarity to protect Filipino communities and natural resources that are threatened by large-scale mining operations.»

As an association of pro-environment activist organizations, and advocates against large-scale mining, the organization is calling for, among others, the scrapping of the Mining Act of 1995 and the passage of an Alternative People's Mining Act. ATM claims that it is not against mining. Rather, it «is against the policy regime in promoting foreign-controlled and export-oriented large-scale mining» (Alyansa Tigil Mina, 2014).

\section{Implementing the Mining Act: an arena of social imaginaries}

The Mining Act was passed in March 1995. As described earlier in this paper, the year witnessed the scores of mining companies filing applications for exploration and mining projects in the Philippines. Barely a year after however, the ecstatic momentum within the national government and the minerals industry dissipated. This was due to a combination of historical, political and economic factors. The process of implementing the Mining Act has demonstrated the clash of social imaginaries.

\section{The disaster that stimulated mass opposition to the Mining Act}

On 24 March 1996, a major tailings spillage occurred at the Marcopper mine in Marinduque Island. An estimated 1.5 to 3 million cubic meters of mine tailings flowed into the Makulapnit River, Boac River, and ultimately the ocean at the Westside of the island (Plumlee, Morton, Boyle, Medlin and Centeno, 2000). It was a catastrophe of unprecedented proportions in the Philippines: agricultural fields were inunda- ted and fishing which was a major livelihood for more than 20,000 families in 42 communities stopped due to the flow of mine tailings burying the channels and the valley floor (SEPO, 2005) ${ }^{14}$. The tailings spillage drew calls from mainly the country's Catholic clergy, church-based organizations, civic-oriented groups, and conservation and environment activists for opposition to mining in general and the outright scrapping of the Mining Act in particular.

\section{Mining Act petitioned as unconstitutional}

Partly as an apprehensive response to «more Marcoppers in waiting», and as a circumspect reaction towards the entry of foreign mining companies to the country, a group of NGOs filed on 10 January 1997 a petition at the Philippine Supreme Court questioning the constitutionality of the Mining Act and its implementing rules and regulations. The group of NGOs was led by the Legal Rights Center-Kasama sa Kalikasan (LRC-KsK). Known as the La Bugal-B'laan Case, the petition called for the Supreme Court to nullify the Philippine Mining Act of 1995 and the FTAA entered into in 1995 by and between the Philippine Government and Tampakan Mineral Resources Corporation, Inc. This company was owned by the Australian Western Mining Corporation (WMC) ${ }^{15}$. Although wMC is the only formal private respondent in the case, the entire minerals industry had actually been handed the legal challenge.

The key issue of the appeal pertains to the unconstitutionality of the FTAA provision of the Mining Act because, as claimed by the petitioners, such provision allows $100 \%$ foreign ownership in large-scale exploration, development, utilization and exploitation of mineral resources in the Philippines by filing FTAAs. Such practice, the petitioners argued, violates the constitutional provision that the natural resources of the Philippines are a national heritage which foreign companies, through FTAAs, should not exploit.

From the time the La Bugal-B'laan case was filed in 1997, the Supreme Court had not issued a decision. In January 2004, after seven years of deliberations, the Supreme Court decided that the provision of the Mining Act allowing foreign-owned corporations to operate and manage mining activities in the country contravenes the Constitution on the grounds that it was in the nature of a «service contract» (Panganiban,

14. Inquests on the accident established that the mines' pollution problems had been occurring for many years. Previous penalties were imposed on the company for its marine disposal of over 200 million metric tons of tailings in Calancan Bay resulting in marine pollution and siltation of about $0.84 \mathrm{~km} 2$ during 1975 to 1986 (Ramos, Cabalda and Banaag, 2000). However, permanent closure was never enforced.

15. In 2004, Western Mining Corporation (Australia) sold the project to the joint venture of Sagittarius Mining, Indophil Resources, Xstrata Holdings and J.P. Morgan. 
2005). The Supreme Court ruled in favour of the petitioners, thereby nullifying the Mining Act's FTAA provisions that allowed the execution of service contracts with foreign firms for exploration and mining ventures. The Supreme Court also declared null and void the FTAA entered into by and between the Philippine Government and WMC.

\section{Enactment of a law to protect indigenous peoples rights}

While the Mining Act was wedged in a legal challenge, a policy to protect indigenous resource rights was enacted by the Congress of the Philippines: Republic Act 8371, otherwise known as the Indigenous Peoples Rights Act (IPRA). Its final passage ${ }^{16}$ on 29 October 1997 was the result of a decade of lobbying, deliberations and consultations by concerned NGOs, peoples' organizations and indigenous peoples' representatives with the support of public interest lawyers who are themselves environmental activists.

The IPRA is a realization of the State policy on rights of indigenous peoples and cultural communities as declared in Section 22, Article II of the Philippine Constitution. The IPRA provides for formulating procedures to set right the historical injustices suffered by indigenous cultural communities/indigenous peoples (ICCS/IPS). In this way, the IPRA exalts the state «by its belated but profoundly significant acknowledgment that some laws are not rooted in the colonial past, but originate and endure in our indigenous heritage» (Leonen, 2004: 154),

The IPRA created the National Commission on Indigenous Peoples (NCIP) as «the primary government agency for the formulation of and implementation of policies, plans and programs to promote and protect the rights and well-being of ICCS/IPs and their ancestral domains as well as their rights thereto" (RA 8371, 1997). The IPRA gives explicit recognition to and protection of the rights of ICCs/IPS "to their ancestral domains to ensure their economic, social and cultural wellbeing». The ancestral domain of ICCS/IPs not only covers the physical land they occupy but the totality of resources and environment including mineral and natural resources underneath. The IPRA provides for priority rights to ICCS/IPS in the extraction, development or exploitation of any natural resources within their ancestral domain (NCIP Administrative Order 3, 2002).

A year after IPRA was enacted, two lawyers, i.e., Isagani Cruz (a retired Supreme Court Justice) and Atty Cesar Europa challenged at the Supreme Court the constitutionality of the IPRA. The petition is perceived by observers as a countermove to the La Bugal-B'laan case. The issues in the petition pertain mainly to the ownership of minerals, property rights, priority rights and self-delineation by the ICCS/IPs. The petitioners also questioned the powers and jurisdictions of the NCIP and the applicability of customary law to the settlement of disputes involving ancestral domains and ancestral lands as violating due process of law.

With the legal challenge confronting the IPRA, the government withheld the release of the NCIP's budget in September 1998. Thus, the NCIP was precluded from performing its functions. Indigenous and other concerned sectors were asking why the government did not also suspend the implementation of the Mining Act, which was similarly facing a legal challenge before the $\mathrm{Su}$ preme Court. On 6 December 2000, the Supreme Court dismissed the petition against the constitutionality of the IPRA (see Supreme Court of the Philippines, 2000). Subsequently, the petitioners filed a motion for reconsideration. However on 21 September 2001, the Supreme Court resolved and declared that the IPRA is constitutional.

\section{Reversal of earlier ruling on the Mining Act}

As earlier noted in this paper, the Supreme Court ruled in January 2004 against the Mining Act. Expectedly, the High Court's decision caused a stir within the Office of President Macapagal-Arroyo, the DENR, and the mining industry. Thus, the MGB enjoined by the private respondents and the minerals industry represented by the COMP immediately appealed the High Tribunal's decision. They argued, among others, that the Philippine Constitution allowed foreign contractors to have reasonable management over mining projects and the Mining Act ensured a fair and equitable sharing of the proceeds of mining projects between the contractor and the state.

The appellants also asserted that annulling the FTAA provisions would deprive the country billions of dollars of potential investments from outside. The President of the CомP argued that the Philippines has already lost at least $\$ 20$ billion-worth of export revenues because the Mining Act was not fully implemented since its passage in 1995 (Clancy, 2005). The comp worked closely with the Office of the Solicitor General and then filed a motion for reconsideration to the Supreme Court to plead for an oral 
hearing of the case in order to explain better the implications of the decision. Thus, an exhaustive constitutional review and the oral hearing in the Supreme Court were held in July 2004.

In December of the same year, the Supreme Court reversed its January 2004 decision: it declared the Mining Act of 1995 as constitutional. The High Court ruled that the mining laws that were questioned earlier - the implementing rules and regulations (IRR) crafted by DENR, and the FTAA with WMC-Philippines which was executed in 1995 - do not breach the constitution. It affirmed the legality of the FTAA. In other words, there was nothing unconstitutional about the mining law's implementing rules and regulations, and foreign ownership of large-scale mining operations is legal.

\section{Conclusion}

This paper looked into the Mining Act of 1995 and the extent to which this law accommodates or responds to the aspirations of constituencies such as local governments, which are assumed to represent the aspirations and concerns of local communities.

Under the Mining Act, the exploitation, development and utilization of the country's mineral resources involve two major actors: the state that owns the resources, represented by the national government; and the mining companies bringing in the much needed foreign capital. However, a mining project is not complete with the settling of the terms and conditions of the contract between these two parties. A mining project involves the default participation of other important players that include the following: a) members of communities whose aspirations and notions of «good life» or «development» have been shaped by their relationship to their homeland and the resources that support it; b) local government officials who assume to represent the interests of their constituent communities; and c) civil society groups whose goals include directly challenging the neoliberal policies of the state.

Resource nationalism is a position that supports the goal of a state to generate revenues. However, this is not true if the particular form of resource nationalism that the state espouses is not shared or concurred by the larger number of its citizens. The case of the Philippines demonstrates the deficient legitimacy of the state - before its citizens at the local level - in mineral resources governance. The anomaly lies in the over centralized approach of the national government in decisions and actions pertinent to the exploitation, development and utilization of the country's mineral wealth. The Mining
Act and its implementing rules and regulations provide for mechanisms to ensure community consultation, local government empowerment, respect and concern for the indigenous cultural communities, and equitable sharing of benefits of natural wealth. However, the national government has not paid attention to actualizing, in full, these principles. This was due to the MGB and other government agencies having been focused on the external dimension of the state's resource nationalist posturing - the government's relationship with foreign investors. The national government, in close partnership with the minerals industry, has devoted so much resources to the prospects of generating foreign investments but serious issues of equity and allocating benefits from mining have remained unresolved in the local communities.

This article demonstrates that local-level decision-making - enshrined in the Local Government Code - brings in the participation of communities in matters of resource governance. The involvement of communities legitimizes the legislative actions of local governments. Local governments formulated relevant ordinances that have restricted or completely blocked the entry of large-scale mining or specific methods such as open pit mining in the provinces. The legislations, which incorporate the concerns of communities whose lifeways are threatened by foreseen adverse impact of mining, have created the efficiency and effectiveness in local resistance against the actions of the national government and mining companies. This resistance becomes long-run because the confrontation between national government and local government is about legislations that clinch the claims of the latter and repudiates the actions of the former. In other words, the confrontation concerns the rule of law and the autonomy of local governments.

Local governments have served as effective corporate bodies for not only articulating the concerns and interests of constituent communities vis-a-vis the distant national government but also securing the legal bases of long-term resistance. The unwelcoming initiatives of local governments towards foreign mining projects aim to conserve mineral resources and prevent foreseen environmental problems that are associated with mining operations. The organizing initiatives of other actors such as civil society groups are critical in creating venues where views and activities of local populations and community leaders are considered, coordinated, and formalized both in the formulation of ordinances as well as in ensuring their implementation. The actions of lower-level political-administrative units manifest sub-national resource nationalism that is founded on locality and affinity to homeland, and confronts the national government in matters of resource governance. 


\section{BIBLIOGRAPHY}

Alyansa Tigil Mina, 2014. About Us: What is the Alyansa Tigil Mina Organization? (retrieved 13 January, 2014, from http://alyansatigilmina.net/about/).

Bicol Mail, 2012. Salceda wants MGB chief sacked (retrieved 28 January, 2014, from http:// www.bicolmail.com/2012/?p=1859).

Bodin Jean, 1955. Six Books of the Commonwealth, abridged and translated by M.J. Tooley (retrieved from Liberty Library of Constitutional Classics http://www.constitution.org/liberlib.htm database Retrieved from http://www.arts.yorku.ca/politics/comninel/courses/3020pdf/six_books.pdf).

Bremmer I. and R Johnston, 2009. The rise and fall of resource nationalism, Survival 51(2), pp. 149-158.

Business Mirror, 2013a (29/01). Governor vows to fight RTC ruling versus Romblon mining ban (retrieved 19 February, 2014, from http://businessmirror.com.ph/index.php/en/ news/regions/8467-governor-vows-to-fightrtc-ruling-versus-romblon-mining-ban).

-, 2013b (27/08). National government not challenging South Cotabato's ban on openpit mining (retrieved 19 February, 2014, from http://www.businessmirror.com.ph/ index.php/en/news/economy/18554-national-government-not-challenging-south-cotabato-s-ban-on-open-pit-mining).

Cabalda M. V., M. A. Banaag, P. N. T. TiDALGO and R.B. Garces, 2002. Sustainable Development in the Philippine Minerals Industry: A Baseline Study, International Institute for Environment and Sustainable Development - World Business Council for Sustainable Development. Mines Minerals and Sustainable Development Project.

Capiz Provincial Ordinance No. 6, 1999. Declaring a moratorium on all large-scale mining activities and the processing of applications for the same in the Province of Capiz for a period of fifteen years and imposing penalties for violation thereof.

Clancy M., 2005. The rebirth of the Philippine mining industry, Makati, Philippines, Philippine Business Leaders Forum Inc., pp. 1-9.

Clarke M. and T. Cummins, 2012. Resource Nationalism: A Gathering Storm?, International Energy Law Review 6, pp. 220-225.

Cleanbiz Asia, 2013 (18/02). Romblon Island targets miners under tough environmental regs (retrieved 19 February, 2014, from http://www.cleanbiz.asia/news/romblon-island-targets-miners-under-tough-environmental-regs\#.UwQT-mKSyZc).

Defensor M. T., 2005 (11 August). Recent developments in the Philippine minerals sector and outlook for the future, paper presented at the Philippine Mining Roadshow, Melbourne.

Department of Interior and Local GoVERNMENT (DILG), 2011 (14 July). Master List of Barangays As of March 31 (retrieved 10, 2014, from http://www.dilg.gov. ph/PDF_File/resources/DILG-Resources2011714-d0ea483a21.pdf).

Disini A. F., 2006. Philippines - 2006, 1. January 2006 (retrieved 7 February, 2014, from http://www.mining-journal.com/ reports/philippines2006?SQ_DESIGN_ NAME=print_friendly).

Emel J., M. T. Huber and M. H. Makene, 2011. Extracting sovereignty: Capital, territory, and gold mining in Tanzania, Political Geography 30 (2), pp. 70-79.

ERnst And Young. 2013. Business Risks Facing Mining and Metals 2013-2014 (retrieved from http://www.ey.com/Publication/ vwLUAssets/Business_risks_facing_mining and_metals_2013\%E2\%80\%932014_ ER0069/\$FILE/Business_risks_facing_mining_and_metals_2013\%E $2 \% 80 \% 932014$ ER0069.pdf).

Executive Order 79, 2012. Institutionalizing and Implementing Reforms in the Philippine Mining Sector Providing Policies and Guidelines to Ensure Environmental Protection and Responsible Mining in the Utilization of Mineral Resources.

Executive Order 270, 2004. National Policy Agenda on Revitalizing Mining in the Philippines (retrieved 24 January, 2014, from http://www.lawphil.net/executive/execord/ eo2004/eo_270_2004.html).

Executive Order 279, 1987. Authorizing the Secretary of Environment and Natural Resources to Negotiate and Conclude Joint Venture, Co-Production, or ProductionSharing Agreements for the Exploration, Development and Utilization of Mineral Resources, and Prescribing the Guidelines for Such Agreements and Those Agreements Involving Technical or Financial Assistance by Foreign-Owned Corporations for LargeScale Exploration, Development, and Utilization of Minerals Full Text published online by the Supreme Court E-Library (retrieved 14 March, 2007, from http:// elibrary.supremecourt.gov.ph/index 10 . 
php?doctype=Executive $\% 20$ Ordersanddocid $=\mathrm{a} 45475 \mathrm{a} 11 \mathrm{ec} 72 \mathrm{~b} 843 \mathrm{~d} 74959 \mathrm{~b} 60 \mathrm{fd} 7 \mathrm{bd} 646$ 9d525320bc3\#sam).

Gonzalez III J. L. 2001. Philippines: Continuing People Power, in J. Funston (ed.), Government and Politics in Southeast Asia, Singapore, Institute of Southeast Asian Studies, pp. 252-290.

Gravelle J., 2012. Resource nationalism - A growing challenge for miners globally, Canadian Mining Journal 133 (10), p. 30.

Haselip J. and G. Hilson, 2005. Winners and losers from industry reforms in the developing world: experience from the electricity and mining sectors, Resources Policy 30 (2), pp. 87-100.

Jurado G. M., 2003. Growth Models, Development Planning, and Implementation in the Philippines, Philippine Journal of Development xxx (1), pp. 1-26.

Kohl B. and L. Farthing, 2012. Material constraints to popular imaginaries: The extractive economy and resource nationalism in Bolivia, Political Geography 31 (4), pp. 225235.

Leonen M. V. F., 2004. Weaving worldviews: implications of constitutional challenges to the Indigenous Peoples Rights Act of 1997, Social Policy and the Law (Journal of the Integrated Bar of the Philippines) 30 (1), pp. 153184.

Litfin K. T., 1997. Sovereignty in World Ecopolitics, Mershon International Studies Review 41, pp. 167-204.

Local Government Code of 1991 (Republic Act No. 7160), 1991. An Act Providing for a Local Government Code of 1991, Congress of the Philippines.

Merriam C. E. J., 2001 (reprint). History of the Theory of Sovereignty Since Rousseau (retrieved from http://republicofbc.pbworks.com/f/ Sovereignty_20difine[1].pdf).

Minda News, 2011a (11/06). South Cot approves environment code, bans open pit mining (retrieved 6 July, 2011, from http://www. mindanews.com/environment/2010/06/11/ south-cot-approves-environmentcode-bansopen-pit-mining/).

—, 2011b (I8/02). Tampakan project is 'catastrophe in the making, militant group says (retrieved 23 July, 2011, from http://www. mindanews.com/topstories/2011/02/18/tampakan-project-is-\%E2\%80\%98catastrophe-inthemaking\%E2\%80\%99-militant-group-says/).
Mining Injustice Solidarity Network (MISN), 2010. PCSD endorsement to Macroasia multi-billion giant deferred: an initial victory for NGOs and indigenous peoples (retrieved 2 October, 2011, from http://www. solidarityresponse.net/palawan-unesco-manand-biosphere-reserve-sold-out-to-miningcompanies-last-government-decision-on30-july/).

Nagan W. P. and A. M. Haddad, 2012. Sovereignty in Theory and Practice, San Diego International Law Journal 13, pp. 430-519.

Ncip Administrative Order No.3, 2002. Revised Guidelines for the Issuance of Certification Precondition and the Free and Prior Informed Consent in Connection with Applications for License, Permit, Agreement or Concession to Implement and or Operate Programs/Projects/Plans/Business or Investments Including Other Similar or Analogous Activities or Undertaking that do not Involve Issuance of License, Permit, Agreement or Concession but Requires the Free and Prior Informed Consent of ICC/IP Community in Ancestral Domain Areas in Accordance with R.A. 8731.

Oriental Mindoro Provincial Ordinance No. 01, 2002. An Ordinance Declaring 25Year Moratorium on Large-Scale Mining in the Province of Oriental Mindoro, Providing Exceptions and Penalties Therefor.

Отто J. M., 1997. Global Mining Taxation Comparative Study, Institute for Global Resources and Management, Colorado School of Mines.

Panganiban A. V., 2005 (3 February). Invest in the whole country, not just in the mining industry, paper presented at the International Mining Investment Conference, Makati City, Philippines.

Philippine Constitution, 1987. The 1987 Constitution of the Republic of the Philippines.

Philstar, 2013 (15 February). Romblon board approves Environment Code (retrieved 19 February, 2014, from http://www.philstar. com/nation/2013/02/15/908843/romblonboard-approves-environment-code).

Plumlee G., S., R. A. Morton, T. P. Boyle, J. H. Mediln and J. A. Centeno, 2000 (May 12-19). An Overview of Mining-Related Environmental and Human Health Issues, $\mathrm{Ma}-$ rinduque, Island, Philippines: Observations from a Joint U.S. Geological Survey - Armed Forces Institute of Pathology Reconnaissance Field Evaluation, U.S. Geological Survey (USGS) Science for a Changing World. 
Ramos F. V., 1993 (26 July). "Let's Seize the Moment!" Message to Congress of His Excellency Fidel V. Ramos President of the Philippines on the State of the Nation (retrieved 31 January, 2014, from http://www.gov. $\mathrm{ph} / 1993 / 07 / 26 /$ fidel-v-ramos-second-stateof-the-nation-address-july-26-1993/).

Ramos H. C., M. V. Cabalda and M. A. BaNAAG, 2000. Tailings dam accidents and the use of chemicals in mining, issues, policy response and lessons learned from the Philippines, paper presented at the International Workshop on Environmental Regulation for Accident Prevention in Mining, Tailings and Chemicals Management, Perth, Australia, 25-27 October 2000.

Republic Act No. 8371, 1997. An Act to Recognize, Protect and Promote the Rights of Indigenous Cultural Communities/Indigenous People, Creating a national Commission of Indigenous People, Establishing Implementing Mechanisms, Appropriating funds Therefor, and for Other Purposes.

Rosenau J., 1995. Sovereignty in a Turbulent World, in G. M. Lyons and M. Mastanduno (eds), Beyond Westphalia? State Sovereignty and International Intervention, Baltimore, Johns Hopkins University Press, pp. 191227.

SEPo (Senate Economic Planning Office), 2005 (Nov). Extracting growth from mining. Policy Insights (PI-06-05) (retrieved 1 July 2007, from www.senate.gov.ph/publications/).

Smith D. and K. Naito, 1998. Asian mining legislation, Resources Policy 24 (2), pp. 125132.

South Cotabato Provincial Ordinance No. 04., 2010. An Ordinance Providing for the Environment Code of the Province of South Cotabato.

SOUTHERN LUZON BUSINESS REVIEW, 2011 (16 December). Bicol Mines Yield Billions: But Salceda says gains artificial.
Stevens P., 2008. National oil companies and international oil companies in the Middle East: Under the shadow of government and the resource nationalism cycle, Journal of World Energy Law and Business 1 (1), pp. 5-30.

Sunstar, 2013 (20 May). Open-pit ban in S. Cotabato stays (retrieved 10 February, 2014, from http://www.sunstar.com.ph/davao/business/2013/05/20/open-pit-ban-s-cotabatostays-283353).

Supreme Court of the Philippines, 2000 (6 December). En Banc [G.R. No. 135385. December 6, 2000] Cruz vs Sec. of Environment and Natural Resources (retrieved 1 April, 2006, from http://www.supremecourt.gov. ph/jurisprudence/2000/dec2000/135385. htm).

TAYlor C., 2004. Modern Social Imaginaries. Durham, North Carolina, Durham, Duke University Press.

United Nations Conference on Trade and Development (unctad) Secretariat, 1997. Management of Commodity Resources in the Context of Sustainable Development, Governance Issues for the Mineral Sector, United Nations Conference on Trade and Development (UNCTAD).

WARD H., 2009. Resource nationalism and sustainable development: a primer and key issues, IIED Working Paper (retrieved 12 Nov, 2011, from http://pubs.iied.org/pdfs/ G02507.pdf).

World Bank - International Finance CorPORATION (WB-IFC), 2003. Mining Reform and the World Bank (retrieved 6 February, 2014, from http://siteresources.worldbank. org/INTOGMC/Resources/miningreformandtheworldbank.pdf).

Yasin R., 2010 (21 January). Globalization and the Sovereign State (retrieved 6 February, 2014, from www.scribd.com/doc/25536152/ Globalization-and-the-Sovereign-State). 